\title{
ANALISIS YURIDIS KEKUATAN HUKUM SERTIPIKAT TANAH ELEKTRONIK DALAM PEMBUKTIAN HUKUM ACARA PERDATA
}

\author{
Dian Dewi Khasanah \\ Sekolah Tinggi Pertanahan Nasional \\ Jl. Tata Bumi No. 5 Banyurade, Sleman, Yogyakarta \\ Corresponding author: Dewinugraha084@gmail.com
}

\author{
Vol 1, No. 1 \\ April 2021 \\ Received \\ April 22 2021 \\ Accepted \\ May $10^{\text {th }} 2021$ \\ Published \\ May $27^{\text {th }} 2021$
}

DOI:

\begin{abstract}
The role of electronic evidence, namely electronic certificates as part of electronic documents in civil cases, is still questionable. The presence of the Electronic Information and Transactions Law, which is the legal umbrella for the validity of electronic certificates, apparently still raises pros and cons, even in the eyes of law enforcers, therefore more specific regulations are needed so that the validity and strength of proof of electronic certificates are no longer questioned in court proceedings, especially civil cases. Electronic certificate or also known as electronic land certificate as one of the products from The Ministry of Agrarian Affairs and Spatial Planning/National Land Agency which is currently being discussed will implement a media transfer process from analog to digital form. For this reason, it is necessary to prepare further regarding regulations to regulate how the later position and strength of evidence from electronic land certificates in Civil Procedure Law as an extension of evidence in civil cases. The method used in writing this scientific paper is legal research with the sociolegal method, namely by normatively examining the regulations regarding the Information dan Electronic Transaction of law in which have been used in civil proceedings in court and by looking at the existing norms and responses that are developing in the community. In the provisions of Article 6 of the Electronic Information and Transactions Law, an electronic document is considered valid if it is accessible, displayable, assured as to its integrity, and accountable. However, because it does not have perfect evidentiary power, it is necessary to accelerate the discussion of the Draft Civil Procedure Law, so that electronic land certificates as part of electronic documents have perfect evidentiary power in court, especially in civil cases.
\end{abstract}

Keywords: Electronic Land Certificate, Evidence, Civil Procedure Law

\section{INTISARI}

Peran alat bukti elektronik yaitu sertipikat elektronik sebagai bagian dari dokumen elektronik dalam perkara perdata sampai saat ini masih dipertanyakan keabsahannya. Kehadiran UU ITE yang menjadi payung hukum dari keabsahan sertipikat elektronik rupanya masih menimbulkan pro dan kontra, bahkan di mata penegak hukum, oleh karenanya dibutuhkan regulasi yang lebih spesifik agar keabsahan dan kekuatan pembuktian dari sertipikat elektronik tidak lagi dipertanyakan dalam beracara di pengadilan khususnya perkara perdata. Sertipikat elektronik atau dapat juga disebut sertipikat tanah elektronik sebagai salah satu produk dari Kementerian Agraria dan Tata Ruang/ Badan Pertanahan Nasional (ATR/BPN) yang saat ini sedang diwacanakan akan diberlakukan atau akan dilaksanakan proses alih media dari bentuk analog ke bentuk digital. Untuk itu perlu dipersiapkan lebih lanjut mengenai regulasi untuk mengatur bagaimana nantinya kedudukan dan kekuatan pembuktian dari sertipikat tanah elektronik dalam Hukum Acara Perdata sebagai perluasan alat bukti pada perkara perdata. Metode yang digunakan dalam penulisan karya ilmiah ini adalah penelitian hukum dengan metode sosio legal, yaitu dengan mengkaji secara yuridis normatif berbagai ketentuan perundangundangan dan pengaturan mengenai dokumen elektronik yang selama ini dapat digunakan dalam beracara secara perdata di pengadilan serta dengan melihat norma dan respon yang ada dan berkembang di tengah masyarakat. Dalam ketentuan Pasal 6 UU ITE, suatu dokumen elektronik dianggap sah apabila dapat diakses, ditampilkan, dijamin keutuhannya, dan dapat dipertanggungjawabkan. Namun karena belum memiliki kekuatan pembuktian yang sempurna, maka perlu segera dipercepat pembahasan mengenai Rancangan Undang-Undang Hukum Acara Perdata, agar sertipikat tanah elektronik sebagai bagian dari dokumen elektronik memiliki kekuatan pembuktian yang sempurna di muka pengadilan khususnya perkara perdata.

Kata Kunci: Sertipikat Tanah Elektronik, Pembuktian, Hukum Acara Perdata 


\section{A. Pendahuluan}

Hukum Acara Perdata yang merupakan hukum formal yang memiliki sifat tertulis dan dituangkan di dalam peraturan perundang-undangan yang memberikan aturan bagaimana dijamin dan ditaatinya hukum perdata materiil melalui perantaraan hakim. Pembuktian dalam suatu proses gugatan perdata sangatlah penting karena menjadi alasan diterima atau tidak diterimanya suatu gugatan oleh hakim. Menurut Soedikno (1998; 5-6) walaupun tidak semua kaidah dan bukti sebagai dasar suatu gugatan harus dibuktikan kebenarannya, namun kaidah serta bukti yang tidak disangkal kebenarannya dan diakui sepenuhnya oleh pihak lawan tidak perlu dilakukan pembuktian kembali.

Hukum pembuktian dalam suatu peradilan perdata mengacu pada prinsipprinsip Hukum Acara Perdata pada umumnya, namun dalam hal menafsirkan atas suatu alat sebagai barang bukti dan memberikan suatu penilaian tersendiri ketika proses beracara di peradilan, hakim memberikan kebebasan kepada para pihak yang bersengketa untuk menghadirkan berbagai alat bukti yang dapat meyakinkan dengan argumentasi yang rasional. Dengan demikian, dari pembuktian tersebut dapat diperoleh gambaran duduk perkaranya dan memudahkan hakim dalam mengambil suatu keputusan dengan adil.

Aturan mengenai pembuktian yang merupakan bagian dari aturan Hukum Acara Perdata merupakan das sollen atau bagaimana seharusnya pembuktian itu dilaksanakan. Sementara itu, pelaksanaan pembuktian dalam suatu perkara perdata merupakan das sein atau bagaimana pelaksanaan pembuktian itu berjalan. Pembuktian adalah proses yang terdapat dalam Hukum Acara Perdata. Terdapat dua hal yang memegang peranan dalam pembuktian, yaitu Alat Bukti dan Peraturan Pembuktian. Adapun jenis-jenis alat bukti menurut Hukum Acara Perdata meliputi bukti tertulis, saksi, persangkaan, pengakuan, dan sumpah. Bambang Waluyo $(1992,35)$ berpendapat bahwa alat bukti merupakan suatu hal, baik itu berupa barang maupun non barang sebagaimana ditetapkan oleh peraturan perundangan dapat dipakai untuk memperkuat ataupun menolak dakwaan, tuntutan ataupun gugatan.

Sistem pembuktian terbagi menjadi dua macam, yaitu sistem pembuktian formal dan sistem pembuktian materiil. Di Indonesia, pada proses penyelesaian suatu perkara perdata, sistem pembuktian yang digunakan adalah sistem pembuktian formal, didasarkan pada data sebagai petunjuk yang bersifat formal yang disampaikan para pihak yang berperkara dan bertujuan menemukan kebenaran formal. Dalam kegiatan ini hakim dalam melaksanakan pembuktian menggunakan alat-alat bukti sebagaimana yang ditetapkan dalam undang-undang saja, tidak didasarkan pada keyakinan yang dimiliki oleh hakim. Sistem pembuktian ini sesuai dengan sistem pembuktian yang terdapat dalam sistem Herzien Inlandsch Reglemen atau lebih dikenal dengan istilah HIR. Pada sistem HIR, hakim dalam melaksanakan pembuktian didasarkan hanya pada alat-alat bukti yang sah, dan dalam proses pengambilan keputusan atau menjatuhkan suatu putusan pada penyelesaian perkara di pengadilan dengan mendasarkan pada alat bukti yang telah ditentukan oleh undang-undang saja.

Perkembangan teknologi informasi dan komunikasi yang pesat berdampak pada banyak bidang. Salah satunya adalah keberadaan informasi atau dokumen 
elektronik yang terus berkembang dan dalam perkembangannya informasi atau dokumen elektronik dapat digunakan sebagai alat bukti hukum di muka pengadilan. Penggunaan alat bukti ini selain mengikuti berbagai perkembangan teknologi yang ada di tengah masyarakat juga dipergunakan sebagai cara untuk mempermudah para penegak hukum khususnya hakim untuk menentukan bagaimana pelaksanaan hukumnya. Adapun hasil cetak dari dokumen elektronik tersebut juga harus dapat dijadikan alat bukti yang sah menurut hukum, sehingga saat ini dalam praktiknya dikenal dan berkembang dengan apa yang dinamakan alat bukti elektronik.

Penyelenggaraan sistem elektronik adalah dengan memanfaatkan sistem elektronik yang dilakukan oleh penyelenggara negara, badan usaha dan atau masyarakat. Suatu bukti elektronik memiliki kekuatan hukum apabila suatu informasi eletronik yang terdapat di dalamnya dapat dijamin keutuhannya, bisa dipertanggungjawabkan, mudah untuk diakses, dan dapat ditampilkan sehingga bisa menerangkan suatu keadaan. Apabila seseorang menyampaikan alat bukti elektronik maka yang bersangkutan juga harus bisa menunjukkan bahwa informasi yang dimilikinya bersumber dari sistem elektronik yang meyakinkan dan dapat dipercaya kredibilitasnya.

\section{B. Metode Penelitian}

Metode yang digunakan dalam penulisan karya ilmiah ini adalah dengan menggunakan metode sosio legal, yaitu mengkaji norma dan respon yang ada dan berkembang di tengah masyarakat terkait sertipikat elektronik serta mengkaji secara yuridis atau normatif dengan melihat berbagai ketentuan perundangundangan. Menurut Irianto \& Shidarta (2011) secara penerapan, metode ini diperlukan untuk menjelaskan bekerjanya hukum dalam kehidupan sehari-hari masyarakat. Peraturan perundang-undangan yang berkaitan dengan sertipikat elektronik adalah HIR, RBg, Kitab Undang-Undang Hukum Perdata, Undang-Undang Pokok Agraria, Undang-Undang No. 11 Tahun 2008 tentang Informasi Transaksi Elektronik (ITE), Peraturan Pemerintah No. 24 Tahun 1997 tentang Pendaftaran Tanah, Peraturan Menteri Agraria dan Tata Ruang/Kepala BPN No. 1 Tahun 2021 tentang Sertipikat Elektronik. Teknik pengumpulan data yang digunakan dalam penulisan karya ilmiah ini adalah menggunakan pendekatan secara kualitatif deskriptif, yaitu pendekatan yang dilakukan dengan menggunakan metode wawancara dengan individu yang secara langsung melakukan kegiatan tersebut dan dari hasil wawancara tersebut akan dideskripsikan atau digambarkan sebagaimana adanya tanpa dilakukan analisis dan ditarik suatu kesimpulan yang berlaku untuk umum. Adapun pada penulisan ini menggunakan metode deskriptif maksudnya adalah dengan mendeskripsikan berbagai data yang diperoleh sebagai hasil dari suatu penelitian.

\section{Hasil dan Pembahasan}

\section{Pentingnya Perlindungan Hukum dalam Sistem Transaksi Elektronik}

Kehadiran internet sebagai basis layanan elektronik di tengah-tengah masyarakat membentuk mereka memiliki budaya baru. Dengan hadirnya internet, masyarakat dapat dengan mudah melakukan komunikasi tanpa batas 
antar wilayah bahkan tanpa dibatasi teritori suatu negara dan dapat dengan mudah mengakses informasi global dengan segala fasilitas dan program yang mendukungnya. Namun realitanya di Indonesia dengan penggunaan teknologi informasi yang berbasis layanan atau transaksi elektronik tersebut belum diikuti dengan perkembangan hukum dan aturan yang dapat mengimbangi cepatnya kemajuan teknologi komunikasi dan informasi. Karenanya dibutuhkan suatu payung hukum untuk melindungi pengguna layanan atau transaksi elekronik dalam menyelesaikan berbagai permasalahan maupun sengketa yang berpotensi muncul di kemudian hari berkaitan dengan dunia maya ini. Hal ini terjadi dikarenakan hukum positif di Indonesia belum bisa menjangkaunya. Berkembangnya teknologi komunikasi dan informasi harus ditunjang dengan adanya hukum materiil, dan juga perlu didukung dengan perangkat hukum formil, yaitu Hukum Acara Perdata sebagai wadah penyelesaian sengketa elektronik yang berpotensi muncul di kemudian hari.

Penggunaan sistem operasional yang akurat terpercaya akan menghasilkan pula dokumen yang akurat dan terpercaya dari segi validitasnya. Di dalam pelaksanaan sebuah sistem elektronik haruslah pula tersertifikasi sehingga dokumen elektronik yang dikeluarkan darinya dapat dipercaya validitasnya. Pembuktian terhadap suatu alat bukti berupa dokumen elektronik juga menyangkut aspek validitas yang dijadikan alat bukti, karena alat bukti elektronik memiliki sifat dan kharakteristik khusus dibandingkan dengan alat bukti non elektronik. Kekhususan atau karakteristik tersebut dikarenakan bentuknya yang disimpan dalam suatu media elektronik. Karena bentuknya tersebut, maka alat bukti elektronik rentan untuk dapat dengan mudah dipalsukan dan disalahgunakan apabila dari sisi keamanan data tidak terlindungi dengan maksimal, sehingga validitas dari data yang akan dijadikan alat bukti sering diragukan keabsahannya dan kebenarannya.

\section{Sertipikat Tanah Elektronik sebagai Bukti Perluasan Alat Bukti dalam Hukum Acara Perdata}

Pemerintah Republik Indonesia melalui Kementerian ATR/BPN berencana untuk memberlakukan dan menerapkan sertipikat elektronik sebagai bukti pemilikan hak atas tanah. Sertipikat elektronik ini berpedoman pada Peraturan Menteri ATR/Kepala BPN Nomor 1 Tahun 2021 tentang Sertipikat Elektronik. Dalam pengaturannya disebutkan bahwa penerbitan sertipikat tanah elektronik dilakukan melalui pendaftaran tanah pertama kali, untuk tanah yang belum terdaftar atau pengganti sertipikat tanah yang sudah terdaftar sebelumnya berupa analog menjadi bentuk digital.

Pendaftaran tanah merupakan rangkaian kegiatan yang dilaksanakan oleh pemerintah secara terus menerus, berkesinambungan secara teratur, meliputi pengumpulan, pengolahan, pembukuan dan penyajian serta pemeliharaan data fisik dan data yuridis dalam bentuk peta dan pendaftaran mengenai bidangbidang tanah dan satuan rumah susun termasuk pemberian surat dan tanda bukti bagi bidang-bidang tanah yang sudah ada haknya dan hak milik atas satuan 
rumah susun serta hak-hak tertentu yang membebani. Pengertian dari pendaftaran tanah tersebut tertuang dalam Pasal 1 ayat (1) PP No. 24 Tahun 1997. Pendaftaran tanah ini dilaksanakan oleh pemerintah untuk memberikan jaminan kepastian hukum bagi rakyat di bidang pertanahan. Pengumpulan data fisik di lapangan dapat dilakukan oleh pihak ketiga, namun hasil akhirnya haruslah dilakukan pengesahan oleh pejabat yang oleh pemerintah dinyatakan memiliki wewenang untuk itu. Hasil pengumpulan data fisik tersebut perlu disahkan oleh pejabat yang berwenang karena bertujuan agar dapat digunakan sebagai alat bukti.

Tujuan dari pendaftaran tanah adalah memberikan jaminan kepastian hukum atau dikenal dengan sebutan recht cadaster atau legal cadaster. Jaminan kepastian hukum yang akan diberikan dalam pendaftaran tanah ini antara lain terkait dengan kepastian status hak yang didaftar, kepastian subyek hak dan obyek hak. Hasil akhir dari pelaksanaan pendaftaran tanah ini berupa sertipikat tanah sebagai tanda bukti hak atas tanah tersebut. Diberikannya jaminan kepastian hukum mengenai hak-hak atas tanah merupakan salah satu tujuan diundangkannya UUPA. Upaya untuk dapat mewujudkannya adalah melalui tersedianya perangkat hukum yang tertulis lengkap dan jelas, serta konsisten. Bagi pihak yang berkepentingan juga akan lebih mudah memperoleh informasi yang terkait dengan tanah tersebut, misalnya informasi mengenai subyek, obyek dan hak atas tanah yang melekat pada tanah tersebut. Dalam pengaturannya, pemerintah berkewajiban menjamin kepastian hukum melalui pendaftaran tanah yang penyelenggaraannya dilaksanakan di seluruh wilayah Republik Indonesia. Pengaturan mengenai kewajiban pemerintah ini terdapat dalam Undang-Undang No. 5 Tahun 1960 Pasal 19.

Telah diuraikan sebelumnya bahwa produk final dari proses penyelenggaraan pendaftaran tanah adalah berupa sertipikat tanah yang akan dilaksanakan alih media dari sertipikat analog menjadi sertipikat tanah elektronik. Dalam sistem HIR dan Hukum Acara Perdata, hakim mendasarkan pembuktian pada alat-alat bukti yang sah, hal ini berarti dalam mengambil keputusan, hakim hanya diperbolehkan mengambil keputusan dengan didasarkan pada alat-alat bukti yang ditetapkan oleh undang-undang saja. Pada Hukum Acara Perdata, alat-alat bukti ditentukan dalam Pasal 164 HIR, 284 RBg dan 1866 KUH Perdata. Dalam hukum pembuktian perdata di Indonesia, secara yuridis formal belum mengakomodir dokumen atau informasi elektronik sebagai alat bukti dalam penyelesaian sengketa melalui pengadilan. Namun dengan lahirnya UndangUndang Nomor 8 Tahun 2007 tentang Dokumen Perusahaan, Indonesia sebetulnya telah mulai mengakomodir penggunaan dokumen elektronik sebagai alat bukti yang sah. Sebagai contoh dalam hukum Pasar Modal, terdapat istilah online trading yang terdapat pada bursa efek serta penggunaan sarana elektronik dalam penyimpanan informasi dan dokumen pada suatu perusahaan.

Secara limitatif telah disebutkan bahwa alat bukti dalam hukum perkara perdata meliputi alat bukti tertulis atau surat, kesaksian atau keterangan saksi, persangkaan, pengakuan dan sumpah. Sertipikat tanah elektronik digolongkan sebagai alat bukti tertulis yang merupakan akta otentik karena akta tersebut 
mempunyai kekuatan pembuktian baik dari segi formil maupun materiilnya. Keistimewaan akta otentik ini terdapat pada kekuatan pembuktian lahir yang artinya akta otentik membuktikan kebenaran dari apa yang dilihat. Dalam hal kekuatan materiilnya walaupun tidak semua akta otentik yang berbentuk akta pejabat memiliki kekuatan pembuktian materiil namun untuk akta otentik yang merupakan partij akta memiliki kekuatan pembuktian materiil. Kekuatan pembuktian materiil inilah yang akan diuji secara formil di muka pengadilan.

Dengan lahirnya Undang-Undang Nomor 11 Tahun 2008 tentang Informasi dan Transaksi Elektronik atau lebih dikenal dengan sebutan UU ITE, maka informasi dan dokumen elektronik menjadi bagian dari alat bukti yang sah dan memiliki akibat hukum yang sah. Sebagaimana ketentuan yang terdapat dalam UU ITE, sertipikat tanah elektronik merupakan alat bukti yang sah di mata hukum. Hal ini diperkuat dengan Pasal 5 ayat (2) dan Pasal 6 UU ITE yang berbunyi informasi dan atau dokumen elektronik dan atau hasil cetak dari dokumen elektronik tersebut merupakan perluasan dari alat bukti yang sah sesuai dengan hukum acara yang belaku di Indonesia. Kehadiran UU ITE ini memberikan prioritas terhadap issue atau permasalahan hukum pembuktian, hal ini dapat dilihat pada penjelasan umum UU ITE yang mengatakan tentang pentingnya pembuktian mengingat informasi elektronik belum terakomodir dalam sistem hukum acara yang ada di Indonesia secara komprehensif namun realitanya juga sangat rentan.

Pembuktian merupakan salah satu tahap yang menentukan dalam penyelesaian perkara di pengadilan. Tujuan dari dilakukannya pembuktian adalah untuk menunjukkan dan menyajikan bukti bagaimana terjadinya suatu peristiwa atau hubungan hukum tertentu yang digunakan sebagai dasar pengajuan gugatan ke pengadilan. Dengan tahap pembuktian maka hakim akan memiliki argumen untuk memberikan putusan dalam suatu penyelesaian perkara. Dalam hal alat bukti dan hukum pembuktian, selain diatur dalam HIR dan RBg, KUH Perdata mengatur pula hal yang sama. Namun karena hukum pembuktian perdata adalah bagian dari Hukum Acara Perdata, maka pengadilan pada dasarnya dalam menangani suatu perkara perdata mendasarkan pada hukum pembuktian dari HIR dan RBg dan Kitab Undang-Undang Hukum Acara Perdata yang berperan sebagai pelengkap pedoman bagi Hukum Perdata. Adapun ketentuan Pasal 164 HIR dan 284 RBg menyebutkan alat bukti dalam suatu perkara perdata terdiri dari alat bukti tertulis atau surat, kesaksian atau keterangan saksi, persangkaan, pengakuan dan sumpah. Alat bukti lain yang dapat dipergunakan untuk memperoleh kebenaran dan kepastian dari peristiwa yang menjadi sengketa atau permasalahan yaitu pemeriksaan setempat dan keterangan ahli atau saksi ahli yang diatur dalam Pasal 153 dan Pasal 154 HIR serta Pasal 180 dan Pasal 181 RBg.

Pembuktian adalah kegiatan penyajian alat bukti yang sah secara hukum yang diserahkan kepada hakim yang melaksanakan pemeriksaan perkara guna memberikan kepastian mengenai kebenaran suatu peristiwa. Kedudukan suatu alat bukti dalam suatu proses persidangan adalah sebagai sarana untuk menguatkan argumen pada saat sidang dilaksanakan di pengadilan. Karenanya 
apabila seseorang ingin memenangkan perkaranya di pengadilan, alat bukti menjadi salah satu kunci bagi pihak yang ingin meyakinkan hakim dalam memenangkan suatu perkara. Namun praktiknya sampai saat ini penggunaan alat bukti yang sah sebagaimana yang terdapat dalam Pasal 5 dan 6 UU ITE yang menjadi dasar dari digunakannya surat elektronik pada persidangan perdata sampai saat ini masih sering dipertanyakan kekuatan pembuktiannya.

Dalam konsideran menimbang yang terdapat dalam Peraturan Menteri ATR/Kepala BPN Nomor 1 Tahun 2021 disampaikan bahwa tujuan dari penerapan pelayanan berbasis elektronik adalah dalam rangka perwujudan modernisasi pelayanan pertanahan untuk meningkatkan indikator kemudahan berusaha dan pelayanan publik kepada masyarakat, sehingga dalam rangka modernisasi tersebut perlu dilaksanakan pengoptimalan dan pemanfaatan teknologi informasi dan komunikasi. Hasil dari modernisasi tersebut adalah pada kegiatan pendaftaran tanah diterbitkan sertipikat tanah dalam bentuk dokumen elektronik.

Seiring dengan perkembangan zaman yang diikuti dengan semakin meningkatnya kegiatan berbasis elektronik, alat pembuktian berupa informasi dan dokumen elektronik dalam suatu perkara perdata akan menjadi sering digunakan untuk memudahkan pelaksanaan hukumnya. Penggunaan dokumen elektronik yang dicetak juga harus bisa digunakan sebagai alat bukti yang sah di mata hukum. Oleh karenanya pada saat ini dikenal dengan alat bukti elektronik. Untuk dapat dikatakan sebagai alat bukti yang sah, maka informasi atau dokumen elektronik tersebut harus memenuhi syarat sebagaimana yang tertuang dalam Pasal 5 dan 6 UU ITE yang menyatakan bahwa informasi atau dokuman elektronik yang dapat dijadikan alat bukti yang sah apabila penggunaan sistem elektronik memenuhi ketentuan sebagaimana yang telah dipersyaratkan oleh UU ITE, yaitu sistem elektronik yang andal dan aman, serta memenuhi persyaratan.

Dalam Pasal 6 UU ITE juga ditegaskan bahwa suatu informasi atau dokumen elektronik akan dianggap sah sepanjang informasi dan data yang tercantum di dalamnya dapat dengan mudah diakses, ditampilkan, dijamin keutuhannya dan dapat dipertanggungjawabkan sehingga dapat menerangkan suatu keadaan. Dalam perkembangannya sebagai contoh untuk dokumen suatu perusahaan, di mana UU Nomor 8 Tahun 1997 tentang Dokumen Perusahaan yang telah mengatur mengenai bukti elektronik yang memberikan penjelasan bahwa apabila suatu dokumen perusahaan yang disimpan dalam bentuk mikrofilm memiliki kedudukan sebagai alat bukti tertulis yang otentik maka dokumen tersebut dapat dijadikan alat bukti yang sah apabila di kemudian hari terjadi sengketa di pengadilan. Sistem elektronik yang digunakan oleh Kementerian ATR/BPN melalui Kantor Pertanahan saat ini telah meliputi pengecekan sertipikat, surat keterangan pendaftaran tanah, informasi nilai tanah atau nilai aset properti dan hak tanggungan yang meliputi cessie dan roya. Penggunaan sistem elektronik tersebut merupakan upaya Kementerian ATR/BPN dalam mengikuti perubahan yang disebabkan adanya perkembangan informasi dan komunikasi sebagai kebutuhan masyarakat dan perkembangan hukum dewasa ini. Perubahan ini juga mempengaruhi cara pandang masyarakat terhadap penggunaan 
dokumen yang awalnya berbasis kertas atau paper based yang kemudian dilakukan alih media dari bentuk analog menjadi bentuk dokumen elektronik. Salah satu tujuan dilaksanakannya alih media ini adalah dalam rangka efisiensi penggunaan kertas atau sering dikenal dengan sebutan paper less. Selain itu dengan digunakannya dokumen elektronik maka dalam hal pembuatan, pengolahan dan penyimpanan informasi elektronik ini akan semakin efisien dari segi biaya dan waktu. Namun wacana alih media dari sertipikat tanah berbentuk analog menjadi sertipikat tanah berbentuk dokumen digital ini masih memerlukan regulasi dan pengaturan lebih lanjut baik dari sisi keamanan maupun keabsahan sertipikat tanah elektronik ini apabila dijadikan alat bukti saat beracara di pengadilan.

\section{Alat Bukti Elektronik sebagai Bukti Berkembangnya Teknologi pada Era Globalisasi}

Semakin berkembangnya teknologi informasi dan komunikasi dalam era globalisasi ini menyebabkan lahirnya berbagai alat bukti elektronik di tengahtengah masyarakat. Namun hadirnya alat bukti elektronik tersebut belum diakomodir dalam undang-undang khususnya hukum positif di Indonesia sehingga kedudukan alat bukti elektronik ini akan memberikan pengaruh kepada hakim dalam pengambilan suatu keputusan terhadap perkara yang berkaitan dengan alat bukti elektronik.

Berdasarkan wawancara bersama dengan Hizbullah Idris, yang merupakan seorang Hakim Tinggi Pengadilan Negeri Surabaya, mengatakan beberapa hakim dalam memutuskan suatu perkara apabila akan menggunakan alat bukti elektronik, masih mempertanyakan keabsahan alat bukti tersebut. Apabila alat bukti tersebut dipergunakan sebagai bukti di muka pengadilan maka para hakim mengharuskan alat bukti elektronik tersebut untuk dicetak menjadi dokumen fisik terlebih dahulu, kemudian hasil cetak dari alat bukti elektronik tersebut wajib divalidasi terlebih dahulu dengan ditandatangani dan diberikan cap basah dari instansi yang mengeluarkan dokumen elektronik tersebut. Hal ini dikarenakan hasil cetak dari dokumen elektronik tidak dapat secara otomatis menjadi alat bukti yang sah apabila tidak dilakukan validasi terlebih dahulu. Hal tersebut perlu dilakukan untuk menambah keyakinan bagi hakim dalam memutus suatu perkara bahwa alat bukti yang ditunjukkan tersebut merupakan alat bukti yang dapat digunakan dalam beracara dan sah di mata hukum.

Berbeda dengan Fauzi, seorang hakim di Pengadilan Negeri di Pulau Natuna yang berpendapat bahwa sertipikat tanah eletronik merupakan alat bukti yang sah dalam pembuktian Hukum Acara Perdata. Dasar keabsahan sertipikat tanah elektronik tersebut terdapat pada Pasal 164 HIR, 284 RBg dan 1866 KUH Perdata dan ditambah dengan ketentuan terbaru yang mengatur mengenai informasi dan dokumen elektronik yaitu UU ITE sebagaimana yang terdapat dalam Pasal 5 dan 6 UU ITE. Suatu sertipikat tanah elektronik adalah dokumen yang berbentuk akta atau surat elektronik yang merupakan hasil atau produk dari sistem elektronik yang dikelola oleh Kementerian Agraria dan Tata Ruang/BPN, sehingga tidak perlu lagi dilakukan validasi ulang. Pihak yang mengajukan sertipikat tanah 
elektronik sebagai alat bukti elektronik dalam persidangan hanya perlu melakukan nazegelen atau pembiayaan materai, yaitu cara mengesahkan suatu produk elektronik dengan cara mencetak produk digital kemudian membawa ke kantor pos untuk dibubuhi materai dan disahkan oleh Pejabat Kantor Pos. Ketentuan nazegelen ini terdapat dalam UU No. 13 Tahun 1985 tentang Biaya Materai, yang intinya menyatakan bahwa suatu dokumen yang apabila belum lunas biaya materai tetap sah, namun tidak bisa dijadikan sebagai alat bukti di depan pengadilan. Apabila dilakukan pencetakan dari dokumen elektronik yang ada tanpa dilakukan nazegelen, maka menurutnya esensi dari sertipikat elektronik menjadi tidak ada karena sama halnya dengan bukti fisik semata sebagai bukti surat otentik. Selain itu pihak yang mengajukan bukti berupa informasi atau dokumen elektronik tersebut harus menghadirkan saksi ahli yang disumpah bahwa keterangan yang diberikan merupakan keterangan yang benar sesuai dengan keilmuan dan keahliannya. Hal tersebut sesuai dengan asas "siapa yang mendalilkan maka pihak tersebutlah yang wajib membuktikan." Dengan demikian esensi dari sertipikat elektronik yang disimpan sebagai informasi atau dokumen elektronik tidak hilang.

Melihat realita yang ada di tengah-tengah masyarakat, sebetulnya tidaklah keliru sepenuhnya apabila seseorang meragukan atau menyangsikan keabsahan hukum pembuktian informasi atau dokumen elektronik, mengingat informasi dan dokumen elektronik tersebut sebagaimana terdapat pada penjelasan dalam UU ITE, masih sangat rentan dalam menopang, mengatur dan mengendalikan aktivitas manusia dan masyarakat dalam dunia maya tersebut. Oleh Karena itu perlu dikaji lebih lanjut mengenai keadilan dalam pembuktian dan keabsahan dari informasi dan dokumen elektronik dari sisi hukum pembuktian untuk dapat digunakan sebagai sebagai alat bukti baru yang disebut dengan alat bukti elektronik dalam sistem hukum positif Indonesia khususnya Hukum Acara Perdata.

Kehadiran saksi ahli sebagai pihak ketiga yang objektif dalam beracara di pengadilan perdata juga bisa membantu menambah pemahaman hakim dalam pemeriksaan guna memberikan pengetahuan dan keyakinan hakim, selain hal utamanya yaitu membantu dalam hal pembuktian. Mengenai keterangan ahli ini diatur dalam ketentuan Pasal 154 HIR dan 247 RBg yang menyebutkan bahwa apabila perkaranya dapat dijelaskan oleh seorang ahli, maka atas permintaan salah satu pihak atau karena jabatannya hakim dapat mengangkat seorang saksi ahli. Hukum pembuktian yang berlaku sampai saat ini, suatu keterangan yang bersifat tertulis dari seseorang yang dibuat di bawah sumpah atau affidavit tidak bisa disamakan dengan keterangan saksi di muka hakim. Hal ini sesuai dengan putusan Mahkamah Agung tanggal 10 Januari Tahun 1957 Nomor 38 K/Sip/1954.

Terkait dengan digunakannya surat elektronik yang dicetak atau dilakukan fotokopi yang umumnya digunakan oleh masyarakat, dapat dikategorikan sebagai pengajuan alat bukti surat dalam pembuktian di pengadilan. Berdasarkan Putusan Mahkamah Agung tanggal 14 April Tahun 1976 menerangkan bahwa fotokopi dapat digunakan sebagai alat bukti dengan syarat fotokopi 
tersebut disertai keterangan sebagai penjelasan atau dengan cara apapun yang sah di mata hukum dapat ditunjukkan bahwa fotokopi tersebut sama dengan aslinya. Saat menyampaikan alat bukti surat atau dokumen, baik berupa akta atau yang berbentuk elektronik apabila diperlukan dalam pemeriksaaan di pengadilan maka dapat dilakukan dengan fotokopi atau dicetak kemudian dimateraikan atau di-nazegelen ke kantor pos agar dapat dikatakan sah sebagai alat bukti. Saat beracara di pengadilan, di hadapan hakim harus dilihat kesesuaian dengan aslinya yang kemudian disahkan oleh hakim sebagai alat bukti yang sah sesuai dengan aslinya dan kemudian diparaf di atas fotokopi bukti surat tersebut. Dengan demikian mengenai kekuatan pembuktian dalam beracara di pengadilan sepenuhnya diserahkan kepada hakim yang menangani dan memutuskan perkara tersebut.

\section{Perlunya pembahasan lebih lanjut Rancangan Undang-Undang Hukum Acara Perdata}

Ketentuan Pasal 1 angka 4, Pasal 5 ayat (3), Pasal 6 dan Pasal 7 UU ITE menjadi dasar bagaimana dokumen elektronik dapat dikatakan memiliki nilai pembuktian. Suatu dokumen elektronik tersebut harus memiliki syarat formil dan materiil yaitu sebagai berikut. Pertama, dokumen elektronik berisi informasi elektronik yang dibuat, diteruskan, dikirimkan, diterima atau disimpan, yang dapat dilihat atau ditampilkan dan/atau didengar melalui komputer atau sistem elektronik, termasuk tulisan, suara, gambar dan seterusnya yang memiliki makna atau arti atau dapat dipahami oleh orang yang mampu memahaminya. Kedua, suatu dokumen elektronik dikatakan sah apabila menggunakan sistem elektronik sesuai dengan ketentuan yang diatur dalam Undang-Undang. Ketiga, suatu dokumen elektronik dapat dikatakan sah apabila informasi yang terdapat di dalamnya dapat diakses, ditampilkan, dijamin keutuhannya dan dapat dipertanggungjawabkan sehingga menerangkan suatu keadaan.

Berdasarkan uraian di atas maka dapat dikatakan kekuatan pembuktian dari suatu dokumen elektronik dalam pembuktian Hukum Acara Perdata disamakan atau disetarakan dengan alat bukti tertulis atau surat. Oleh karena itu, dapat dikatakan bahwa sertipikat tanah elektronik apabila digunakan dalam beracara pada persidangan perdata merupakan alat bukti yang sah, walaupun harus diakui bahwa belum semua pihak menilai pembuktian dari sertipikat tanah elektronik dikatakan sepenuhnya sempurna, sehingga memerlukan regulasi dan pengaturan ketentuan lebih lanjut.

Dengan lahirnya UU ITE, maka kedudukan dari sertipikat tanah elektronik yang merupakan bagian dari dokumen elektronik yang menjadi salah satu alat bukti yang sah dalam beacara secara perdata di pengadilan. Dengan adanya dokumen elektronik yang menjadi salah satu alat bukti yang sah tersebut, maka ketentuan mengenai macam-macam alat bukti dalam beracara secara perdata di pengadilan tidak hanya terbatas dan terikat pada apa yang tertera pada ketentuan HIR, RBg maupun Kitab Undang-Undang Hukum Perdata saja, namun juga meluas pada apa yang telah ditentukan pada UU ITE dan dimungkinkan juga 
dilakukan pemeriksaan saksi melalui suatu media elektronik. Dengan diberlakukan dan diperbolehkannya dokumen elektronik sebagai alat bukti yang sah dalam pengadilan, maka hal ini menunjukkan sebetulnya alat bukti dalam beracara di pengadilan tidak bersifat limitatif lagi namun saat ini bersifat terbuka.

Berkembangnya teknologi informasi dan komunikasi secara global serta budaya yang berkembang dalam masyarakat ikut mempengaruhi berbagai hubungan keperdataan yang ada pada masyarakat sampai saat ini. Dengan realita tersebut pengaturan mengenai pembuktian dan Rancangan UndangUndang Hukum Acara Perdata yang sampai saat ini masih dalam proses penyempurnaan, yaitu melalui Pasal 83 Rancangan Undang-Undang Hukum Acara Perdata telah direncanakan dalam hal pengaturan mengenai pembuktian ini akan bersifat terbuka. Dengan melihat ayat (1) dalam Pasal tersebut yang menyebutkan bahwa "pembuktian dapat dilakukan dengan semua alat bukti, kecuali undang-undang menentukan lain". Selanjutnya pada ayat (2) dikatakan bahwa "penilaian terhadap pembuktian diserahkan pada hakim, kecuali undangundang menentukan lain."

\section{Kesimpulan}

1. Sertipikat tanah eletronik sebagai bagian dari dokumen elektronik merupakan alat bukti yang sah untuk dapat beracara di pengadilan. Ketentuan yang mengatur keabsahan dokumen elektronik ini terdapat dalam Pasal 6 UU ITE, yaitu dapat diakses, ditampilkan, dijamin keutuhannya, dan dapat dipertanggungjawabkan.

2. Sertipikat tanah elektronik yang merupakan bagian dari dokumen elektronik merupakan perluasan dari alat bukti sebagaimana yang ditentukan dalam HIR, Rbg maupun Kitab Undang-Undang Hukum Perdata. Oleh karena itu dapat dikatakan bahwa alat bukti dalam suaru perkara perdata saat ini tidak lagi bersifat limitatif namun juga terbuka sepanjang sah secara hukum dan bukan sesuatu yang dilarang oleh undang-undang.

3. Diperlukan regulasi atau pengaturan yang lebih rinci dan spesifik dalam memberikan kepastian hukum bagi setiap perkara perdata khususnya terkait dengan sertipikat tanah elektronik sebagai bagian dari dokumen elektronik memiliki kekuatan pembuktian yang sempurna.

\section{Rekomendasi}

Dalam mengikuti perkembangan teknologi informasi yang semakin cepat saat ini, pemerintah perlu mempercepat pembahasan Rancangan Undang-Undang Hukum Acara Perdata agar segala hal terkait dengan informasi dan dokumen elektronik mendapatkan payung hukum dan kepastian hukum dalam menyelesaikan perkara di pengadilan khususnya perkara perdata di pengadilan. Dengan payung hukum tersebut maka keberadaan sertipikat tanah elektronik sebagai bagian dari dokumen eletronik menjadi alat bukti yang tidak lagi dipertanyakan keabsahannya karena memiliki perlindungan dari Hukum Positif yang berlaku di Indonesia. 


\section{Daftar Pustaka}

Army, E. (2020). Bukti Elektronik Dalam Praktek Peradilan. Sinar Grafika, Jakarta Timur.

Bakhri, S. (2019). Dinamika Hukum Pembuktian Dalam Capaian Keadilan. Raja Grafindo Persada, Depok.

Fakhirah, E. L. (2017). Bukti Elektronik Dalam Sistem Pembuktian Perdata. Refika Aditama, Bandung.

H. Ishaq, 2014, Pengantar Hukum Indonesia (PHI), PT. Raja Grafindo Persada, Jakarta. Irianto, S \& Shidarta. (2011). Metode Penelitian Hukum: Konstelasi dan Refleksi. Yayasan Obor Indonesia, Jakarta.

Mertokusumo, S. (1998). Hukum Acara Perdata Indonesia. Liberty, Yogyakarta.

Waluyo, B. (1992). Sistem Pembuktian dalam Peradilan Indonesia. Sinar Grafika. Jakarta.

\section{Peraturan Perundang-undangan}

HIR, Stb.1848 No. 16 jo Stb. 1941 Nomor 44.

RBg, Stb.1972 Nomor 227.

Kitab Undang-Undang Hukum Perdata.

Undang-Undang Nomor 5 Tahun 1960 tentang Peraturan Dasar Pokok - Pokok Agraria Undang-Undang Nomor 8 tahun 1997 tentang Dokumen Perusahaan.

Undang-Undang Nomor 11 Tahun 2008 tentang Informasi dan Transaksi Elektronik. Undang-Undang Nomor 13 Tahun 1985 tentang Biaya Materai

Peraturan Menteri Agrariadan Tata Ruang/Kepala Badan Pertanahan Nasional Nomor 1 Tahun 2021 tentang Sertipikat Elektronik. 